\title{
CFD simulation of designed coalescing plates for separating water and oil in water treatment plants used in petroleum projects
}

\author{
Petrol projelerinde kullanılan su arıtma tesislerinde su ve petrolün \\ ayrıştırılması için tasarlanan birleştirilmiş plakaların CFD simülasyonu
}

\author{
Sedat YAYLA ${ }^{1 *}$, Soran Sabah IBRAHIM11, Ali Bahadır OLCAY²
}

\author{
${ }^{1}$ Mechanical Engineering Department, Faculty of Engineering and Architecture, Yuzuncu Yil University, Van, Turkey. \\ syayla@yyu.edu.tr, soransabahibrahim@gmail.com \\ ${ }^{2}$ Mechanical Engineering Department, Faculty of Engineering, Yeditepe University, Istanbul, Turkey. \\ bahadir.olcay@yeditepe.edu.tr
}

Received/Geliş Tarihi: 22.02.2016, Accepted/Kabul Tarihi: 25.04.2016

* Corresponding author/Yazışılan Yazar

doi: $10.5505 /$ pajes.2016.67944

Research Article/Araștırma Makalesi

\section{Abstract}

Petroleum production generates an immense amount of oily polluted water which may have harmful effects on environment. At the same time, produced water is the biggest waste stream produced in the petroleum industry. In the past decades produced water treatment was the point of attention. However, the processes of treatment to separating water and oil have been enhanced gradually. This study used a two-dimensional computational fluid dynamics (CFD) model to investigate the effect of space between coalescing plates, orifice diameter and mixture inlet velocity on separation efficiency. Spacing values of $8,12,16,20,24 \mathrm{~mm}$ between plates, orifice diameters of 10 $15,20 \mathrm{~mm}$ with different cross sections (e.g., cylindrical, rectangular, ellipse, and triangle) along with four different mixture inlet velocities of $0.02,0.03,0.04,0.05 \mathrm{~m} / \mathrm{s}$ were utilized to discover the effect of each parameter on the separation efficiency. The investigation revealed that the increase in the distance between plates was inversely proportional to the separation efficiency and the increase in the velocity of the mixture or mass flow rate inlet was inversely proportional to the separation efficiency. It was also found that the highest separation efficiency was obtained for the cylindrical shape with a hole diameter of $15 \mathrm{~mm}$. It was also observed that the separation efficiency varied between $25 \%$ and $99.25 \%$ depending on the values of mixture inlet velocities and distance between plates.

Keywords: CFD, Two-phase flow, Velocity of mixture, Volume of fluid, Laminar flow

\section{Introduction}

Underground and well fluids are often compound mixtures of gas, oil, and water. These fluids are required to be separated so that each of them can be used for a specific application. One of the easiest ways to separate oil from water is the use of utilizing tank in which gravity enforces the heavier fluid to be at the bottom of the tank. For example, water, heavier than oil, sinks to the lower part of the tank and the oil stays at the top of the tank. Therefore, oil can be either extracted for further treatment or sent back to reservoir tanks. As a result, it is necessary to remove water from the oil prior to the delivery to the pipelines [1]. The oil industry has various issues in the process of separating water from oil. For the purpose of increasing oil production, gas and oil companies continuously seek for more efficient methods to decrease the amount of water in the mixture. Since the eighteenth century, water was produced as a mixture of water and hydrocarbon. This has disappointed and challenged the industry on by what means to
Öz

Petrol üretimi, cevreye zararlı etkileri olabilecek bol miktarda yağ ile kirlenmiş su ortaya çılkarmaktadır. Aynı zamanda üretilen su petrol endüstrisinin ürettiği en büyük atık akımdır. Geçmis yıllarda dikkat üretilen su işlemleri üzerineyken suyu yağdan ayırma yöntemleri zamanla önemli șekilde iyileștirildi. Bu çalıșma kapsamında birleșik plakalarda, plakalar arasındaki mesafenin, orifis çapının ve karışım giriș hızının ayırma verimine olan etkilerini incelemek için iki-boyutlu hesaplamalı akıșkanlar dinamiği (HAD) modeli kullanıldı. Ayrılma verimini etkiyen parametreleri belirleyebilmek için 8, 12, 16, 20, 24 mm plakalar arası mesafesi, 10, 15, 20 mm farklı enine kesit (örneğin, silindirik, dikdörtgen, elips ve üçgen) orifis çap değerleri ile 0.02, 0.03, $0.04,0.05 \mathrm{~m} / \mathrm{s}$ olan dört farklı karıșım giris hızları kullanıldı. Bu inceleme plakalar arası mesafedeki artısın, karıșm giris hızındaki artışın veya kütle akış debisinin ayrılma verimi ile ters orantılı olduğunu ortaya çlkardı. Diğer taraftan en yüksek ayrılma verimi 15 $\mathrm{mm}$ delik çaplı silindir șeklindeki orifiste elde edildi. Üstelik ayrılma veriminin, plakalar arasındaki mesafeye ve karıșım giriș hızlarına bağlı olarak \%25'ten \%99.25'e kadar değiștiği gözlemlenmiștir.

Anahtar kelimeler: HAD, İki fazlı akıș, Karıșımın hızı, Akıșkanın hacmi, Laminer akıș separate the disposable from the previous. Over the years, different methods of separation have been invented such as; installation of stock reservoir, skim pit, gun barrel, free water knock out instrument while the greatest novel one has become the water treatment plant. Once the fluids delivered to the separation tank, the oil and gas will be separated while the remained water flows through the water treatment plant for further processing [2].

The water, produced and brought to the surface with natural gas and crude oil, is typically polluted cannot be used for drinking or irrigation. The biggest waste by volume in oil production process is generally water [3]-[5]. The compound of the fluid mixture relays on how existence of crude oil or gas is generated. It usually contains either gaseous hydrocarbon or liquid, suspends or dissolved solids, settling like sand or slit, and inserted fluids and additives. Because of the high level of the toxicity and solubility in the remained water, it enlarges a major environmental risk for mankind [7]. There is testimony that hydrocarbon could give rise to cancer and other serious 
diseases, in accordance with the U.S. environmental protection agency [8]. That is why decreasing exposure to these materials is fundamental for preserving marine and human life [9].

In the oil manufacturing industry, generated water is the main volume waste stream. The ratio of water to oil is nearly $3: 1$ [10]. It subsists as a result of manufacture gas and oil from subsurface tanks [11]. The amount of water produced from the oil manufacturing process has augmented sensationally and it is not stable through an oils operation time [12]. It is proven that there is a negative correlation between water production and oil [3]. It a number of older fields, the water could surpass more than $90 \%$ [10],[12]. Globally, the amount of water production is anticipated to raise in the upcoming, this states that the influence of clearing manufactured water into the ecosystem will come to be an immense concern [12], [6]. Presently, arise number of researchers have utilized computational fluid dynamics (CFD) to examine oil water separation. It has also been utilized as basis of oil water separation experiments because defining the effect of various geometries and operation process on the efficiency of separation by doing and carrying out experimentation can be quite complex and costly [13]-[16]. CFD computation has proven to be more applicable and advantageous with regards to the experiments. Therefore, CFD program is utilized in this study [17],[18].

\section{Methods}

CFD is a numerical technique facilitating the investigation with the help of fluid dynamics. Utilizing CFD program assists in building computational model which represents a device or system to be examined. In this program, physical and chemical properties of the fluid are typically applied and the program solves the governing equations to provide output parameters for the fluid dynamics and associated physical phenomena. Thus, CFD program can be seen as a complicated computational-based designing and analysis procedure [19].

Volume of fluid (VOF) model is, on the other hand, a superficial-tracing technique utilized to an immovable Eulerian mesh. It is applied for calculating additional unmixable fluids where the location of the boundary among the fluids is of interest. In this model, a set of momentum equation is shared by the fluids, and the volume of the fraction of every fluid in all computation cells is affected throughout the domain. The utilization of the VOF formulation comprise stratified streams, filling, sloshing, free-superficial streams, the movement of liquid after a dam breakdown and the movement of great bubbles in a liquid boundary [20].

The water was selected as primary phase since the water volume fraction was higher than in oil-water mixture. Here, the oil was termed as a secondary phase. The ratio of water to oil was 3:1 while no-slip was set for both phases. Figure 1 shows the diagram for coalescing plate and entrance of mixture along with the water and oil exit can be seen. Computational domain illustrated in Figure 2 has mass flow rate inlet boundary at the left side while pressure outlet boundary condition was imposed at the exit of the boundary and two-cell zones were used. The mass flow inlet was utilized because it was the simplest condition for the inlet boundary. Surface tension effect had to be active in two layers of water and oil, the surface tension coefficient was taken as zero in gravity separation for laminar mode flow.
Figure 3 shows the enlarged view of the plate positions and the dimensions of the distance between plates along with the length of the plate. The width of the computational domain was set to $537 \mathrm{~mm}$ while the distance between the plates were chosen to be $8,12,16,20$ and $24 \mathrm{~mm}$.

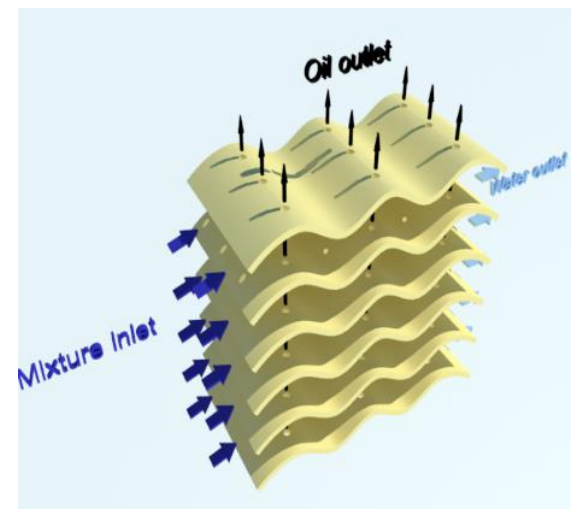

Figure 1: Coalescing plate diagram water and oil direction flow.

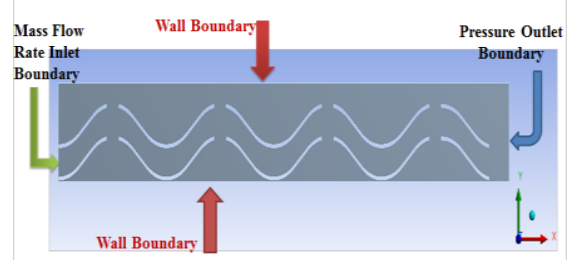

Figure 2: Front view of coalescing plate diagram with boundary conditions.

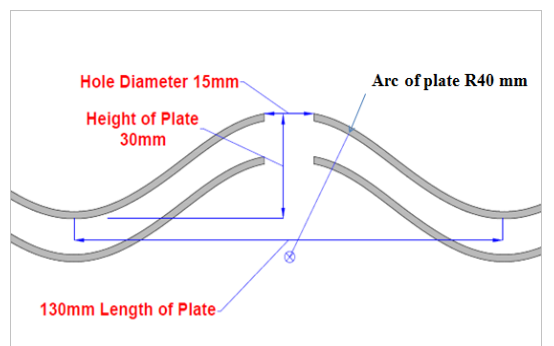

Figure 3: Boundary plate dimensions.

Quadrilateral elements shown in Figure 4 were placed into the computational domain ranging from 29000 elements to 39000 elements for the distance between the plates of $8 \mathrm{~mm}$ and $24 \mathrm{~mm}$, respectively. Optimal mesh size was determined based on the average velocity and the characteristics of the fluid velocity between the plates. Specifically, minimum mesh sizes were set to $0.00014 \mathrm{~m}$ near the walls to capture velocity gradients while maximum mesh sizes stayed at $0.001 \mathrm{~m}$ in other part of the domain. The quality of the mesh was also monitored based on the skewness of the elements. Most of the elements' skewness were below 0.25 due to the square shape of the computational domain. However, few elements around the corner of plates showed maximum skewness of 0.45 considered to be in good cell quality. 


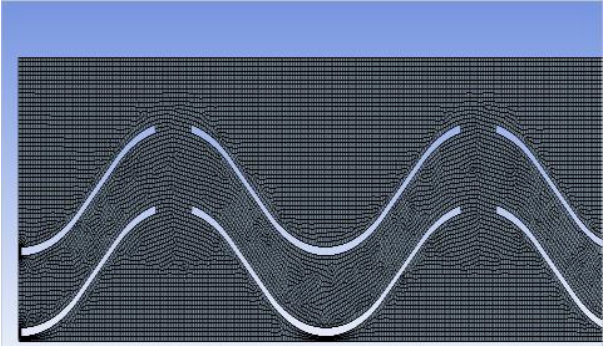

Figure 4: Mesh elements in the computational domain.

In the present study, Reynolds number for the flow simulation was defined as $\mathrm{Re}=\rho \mathrm{Vd}_{\mathrm{h}} / \mu$ was density of fluid, $V$ was the velocity of fluid, $d_{h}$ was equivalent diameter of the flow channel. Reynolds number of the studied cases in the present study stayed in the laminar flow regime; therefore, governing equations for laminar flows were implemented for the solver.

Volume of fraction equation is the following of the user boundary among the phases and skilled by the resolution of a permanency equation. For the phases, this equation has the pursuing arrangement [20],[21].

$\frac{1}{\rho q}\left[\nabla \cdot(\alpha q * \rho q * v q)=S \alpha q+\sum_{p=1}^{n=1}(m p q-m q p)\right.$

Surface tension continuum force equation is given as [25].

$$
\gamma=\frac{F}{L}
$$

Momentum equation can be given as,

$$
\nabla \cdot(\rho v v)=-\nabla p+\nabla \cdot[\mu(\nabla v+\nabla V t)]+\rho g+F
$$

Mass flow rate equation can be expressed as Mass flow from each phase;

$$
\rho \text { phase } * \text { area phase } * V
$$

Equation (4) states the continuity equation or conversation of mass, common method of the mass improvement equating and validated for incompressible fluids in addition to compressible streams. The basis $(\mathrm{Sm})$ is the mass additional to the main part of fluid from or bulk phase the droplet part of fluid or globule phase shown below [20],[21].

$$
\nabla(\rho \mathrm{V})=\mathrm{Sm}
$$

The separation performance of an oil-water separator system was assessed as stated by less volume of water separated. In other side, the high stability of mixture designates the minimum percentage of water separation from oil in water mixture [22],[23].

Oil removal separation efficiency

$$
(\%)=(\mathrm{CI}-\mathrm{CO}) / \mathrm{C}
$$

Here, CI stands for water inlet oil content while CO represents for water outlet oil content.

Numerical results in the present study were validated with Ivanenko et al. [27]. The validation of the results was performed based on the average velocities between the plates when the distance between the plates were the same for both
Ivanenko et al. [27] and the present study. Both average velocity between the plates and the characteristics of the fluid flow were in good agreement with Ivanenko et al. [27].

\section{Results and discussion}

The use of coalescing plates in the removal of oil from water is a commonly used method in industry. However, determination of separation efficiency can be difficult to measure depending on the varied parameters. In the present study, a two-dimensional computational fluid dynamics model was prepared to simulate removal process of oil from water in coalescing plates system.

Figure 5 indicates that when the flow inlet velocity is $0.0500 \mathrm{~m} / \mathrm{sec}$ and the distance between plates is $20 \mathrm{~mm}$, the flow is laminar and the stream line velocity arises in a curvilinear channel to $0.16511 \mathrm{~m} / \mathrm{sec}$. The region of the whirl flow can be observed in the curvilinear channel and at the orifice diameter of the plate as discussed by Ivanenko et al. [27].

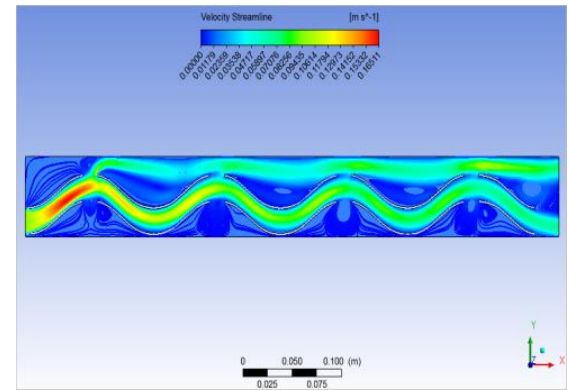

Figure 5: Velocity Stream lines when $\mathrm{h}=20$ and inlet velocity $=0.05 \mathrm{~m} / \mathrm{sec}$.

Figure 6 shows that when the velocity of the mixture inlet is $0.0300 \mathrm{~m} / \mathrm{sec}$ and the distance between plates becomes 12 $\mathrm{mm}$, the velocity magnitude rises to $0.10061 \mathrm{~m} / \mathrm{sec}$. This variation in the velocity leads to the occurrence of the separation in the coalescing plate. It is important that the velocity magnitude must be higher than the velocity of mixture flow inlet [27].

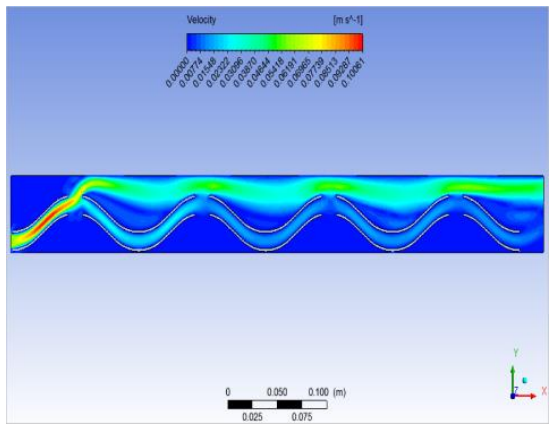

Figure 6: Magnitude of velocity when $\mathrm{h}=12$ and velocity $=0.03 \mathrm{~m} / \mathrm{sec}$.

Figure 7 expresses the rise of velocity vector 0.16511 $\mathrm{m} / \mathrm{secwhen}$ using the distance between plates to be $20 \mathrm{~mm}$ compared to the velocity of the mixture inlet to $0.0500 \mathrm{~m} / \mathrm{sec}$. This is mostly caused by the impairment of velocity vector in the coalescing plate. It is noticed that the velocity vector is higher than the velocity of mixture flow inlet which is very essential for separation process for all the studied cases [27]. 


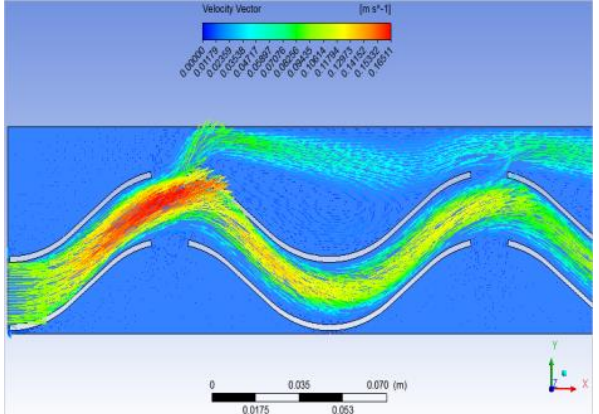

Figure 7: Velocity vector when $\mathrm{h}=20$ and velocity $0.05 \mathrm{~m} / \mathrm{sec}$.

The surpass of oil particle leads to an increase rate larger than the velocity laminar flow surrounding them. The velocity difference leads to addition particle collisions of smaller and bigger globules. The globules become larger and speed up their upward movement as a result they trapped by coalescing plates or corrugated plates on the top section of the plate. The velocity will be higher compared to the velocity of the mixture in the gap. All of the figures given below show that when the distance between plates were $8,12,16,20,24 \mathrm{~mm}$, both $\mathrm{x}$ and $\mathrm{y}$-velocities increased.

Figure 8 displays that using the velocity of mixture inlet $0.0300 \mathrm{~m} / \mathrm{sec}$ and the distance between plates $12 \mathrm{~mm}$ results in the rise of the $x$-velocity to $0.08406 \mathrm{~m} / \mathrm{sec}$, the most fundamental part is that the $\mathrm{x}$-velocity is higher than the velocity of mixture flow inlet.

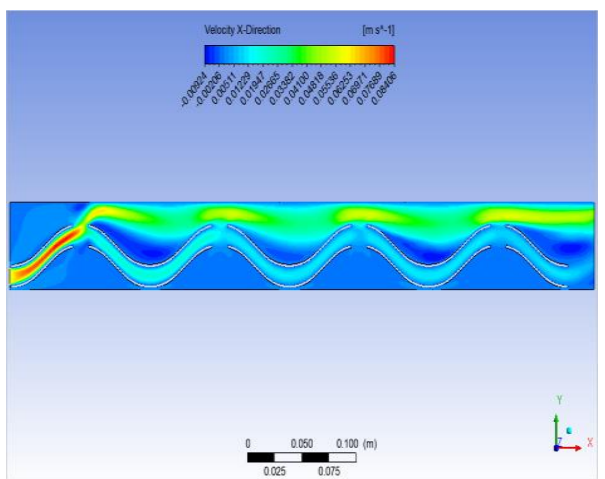

Figure 8: Velocity in $\mathrm{x}$-direction when $\mathrm{h}=12$ and velocity $=0.03 \mathrm{~m} / \mathrm{sec}$.

Figure 9 expresses that applying the velocity of mixture inlet as $0.0300 \mathrm{~m} / \mathrm{sec}$ and the distance between plates to be $12 \mathrm{~mm}$ increased the $y$-velocity to $0.06372 \mathrm{~m} / \mathrm{sec}$. The high vertical velocity (y-axis) assists the separation of bulk phase and globule phase [24],[25],[27].

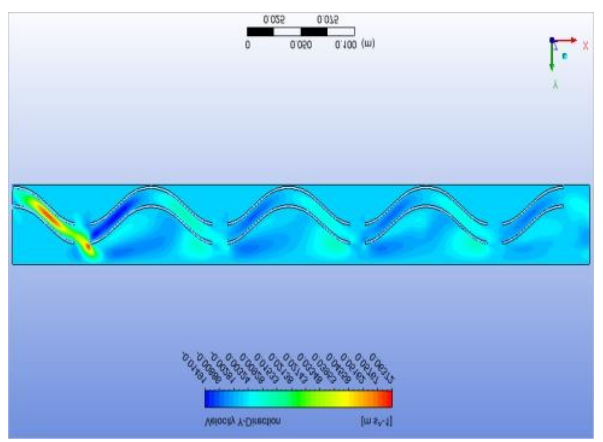

Figure 9: Velocity in $\mathrm{y}$-direction when $\mathrm{h}=12$ and velocity $=0.03 \mathrm{~m} / \mathrm{sec}$.
The volume of fraction is the key for indicating separation efficiency; this research observed a fluid entry with percentage of water $71.38 \%$ and oil is $28.62 \%$ in the outline. This result agrees with studies in this field which is the amount of 1:3 oil in water. The water and oil layers are separated clearly with an interface and a mixed section between the water and oil is attained by volume of fluid VOF simulation model [28]. When the layer of water separated obviously indicate high efficiency. However when water layers law or not obviously seen in the outline indicate law efficiency. When the distances between plates are increased the separation efficiency and the water volume fraction are decreased in the outlet.

Figure 10 indicates that when the oil volume of fraction is $0.28616 \%$ velocity of mixture inlet $0.04 \mathrm{~m} / \mathrm{sec}$ and applying the distance between plates $16 \mathrm{~mm}$, the separation efficiency is $80.00 \%$. When the layer of oil invisible in the water outline indicates high separation efficiency. Conversely, when the oil layers obviously displays in the water outline indicate law separation efficiency.

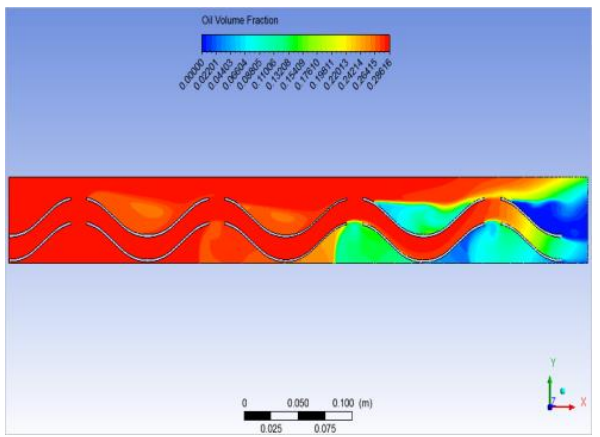

Figure 10: Oil volume of fraction when $\mathrm{h}=16 \mathrm{~mm}$ and velocity $=0.04 \mathrm{~m} / \mathrm{sec}$.

The mixture stability assessed in accordance to the minimum quantity of separated water. In another way, the minimum percentage of separated water denotes the high stability of the mixture. This study found that the separation efficiency shown in Figure 11 varied between 24\% and 99\% for different plate spacing values ranged $8,12,16,20,24 \mathrm{~mm}$ and mixture inlet velocities from $0.02 \mathrm{~m} / \mathrm{s}$ to $0.05 \mathrm{~m} / \mathrm{s}$. As the distance between plates increased, oil removal efficiency decreased. Also, when velocity of the mixture or mass flow rate of the mixture increased oil removal separation efficiency decreased. The increase of velocity of mixture inlet leads to the increase in the mass flow rate of the mixture inlet $0.732,1.0974,1.46,1.82$, $2.914 \mathrm{~kg} / \mathrm{sec}$, which cause the decrease in the separation efficiency. This is confirmed by other studies [26],[27],[29].

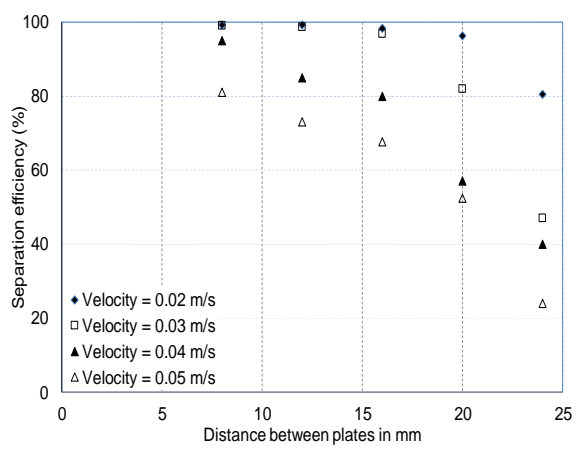

Figure 11: Separation efficiency and distance between plates, when velocity $0.02,0.03,0.04,0.05 \mathrm{~m} / \mathrm{sec}$. 


\section{Conclusions}

In the current study, a research is carried out to have an understanding on the oil-water two phase flow phenomenon in coalescing or corrugating plate and its separation. The research supply's an outline with using ANSYS FLUENT commercially presented CFD simulation software so as to yield the benefit of using a CFD and selected VOF oil-water phase's model.

In general oil industry consists of the process of exploration, extraction and marketing. Various types of procedures are available for separating this compound mixture. The most important compositions are oil, gas and water, these substances are required to be separated before the transmission and marketing. The quality of water has been estimated for a number of fluid systems in both water and oil continuous regime if the water is primary phase and oil is secondary phase, by coalescing plate separator water and oil can be separated.

Produced water treatment can be classified in several major processes every class could be divided in to some subclasses. The most widely utilized process of produced water treatment is coalescing or corrugated plate. Coalescing plate applied in this process in order to accelerate the separation process. The election of an operation for handling is so much relying on the characteristic of the produced water and its source. It also depends on the eventual purpose of its utilization. In this research parameters such as velocity, orifice diameter, distance between plates, and volume of fraction and separation efficiency have been observed. It is found that the separation efficiency has negative correlation with velocity. Additionally, the smaller the spacing between plates is, the better the separation efficiency. In this research several hole diameter have been observed 10, 15, $20 \mathrm{~mm}$ with different shape such as (cylindrical, rectangular, ellipse, and triangle). It is found that the best separation efficiency was by applying coalescing plates which has cylindrical shape with a hole diameter of $15 \mathrm{~mm}$ diameter.

\section{Nomenclature}

Symbol Description

$\begin{array}{llll}\mathrm{A} & : & \text { Area } & \left(\mathrm{m}^{2}\right), \\ \mathrm{M} & : & \text { Mass } & (\mathrm{kg}), \\ \mathrm{m} & : & \text { Mass flow rate } & (\mathrm{kg} / \mathrm{s}) \\ \mathrm{F} & : & \text { Force } & (\mathrm{N}), \\ \mathrm{Q} & : & \text { Volumetric flow rate } & \left(\mathrm{m}^{3} / \mathrm{s}\right) \\ \mathrm{Re} & : & \text { Reynolds number } \\ \mathrm{u} & : & \text { Local velocity } & \\ \mathrm{V} & : & \text { Velocities } & (\mathrm{m} / \mathrm{s}) \\ \mathrm{W} & : & \text { Mass flow Density rate } & (\mathrm{m} / \mathrm{s}), \\ \rho & : & \text { Density } & (\mathrm{kg} / \mathrm{s}) \\ \mu & : & \text { Viscosity } & \left(\mathrm{kg} / \mathrm{m}^{3}\right) \\ \gamma & : & \text { Surface tension } & (\mathrm{kg} / \mathrm{ms}) \\ \alpha & : & \text { Volume of fraction } & (\mathrm{N} / \mathrm{m}) \\ \nabla & : & \text { Delta or nabla } & (\%), \\ \partial & : & \text { Partial } & \\ L & : & \text { length } & \\ \mathrm{h} & : & \text { distance between plates } & \mathrm{mm}, \\ \mathrm{D} & : \text { hole diameter } & \mathrm{mm},\end{array}$

$\begin{array}{clll}\mathrm{p} & : & \text { phase one } & \\ \mathrm{q} & : & \text { phase two } & \\ \mathrm{Hi} & : & \text { height of the plate } & \mathrm{mm} \\ \mathrm{Le} & : & \text { length of the plate } & \mathrm{mm}, \\ \mathrm{Hd} & : & \text { plate hole diameter } & \mathrm{mm} .\end{array}$

\section{References}

[1] Algifri AH, Bhardwaj RK, Rao YVN. "Turbulence measurements in decaying swirl flow in a pipe". Applied Scientific Research, 45(3), 233-250, 1988.

[2] Escobar OM. The graduate school performance evaluation of modified liquid-liquid cylindrical cyclone. Petroleum Engineering The Graduate School The University of Tulsa, 2005.

[3] Razi FA, Pendashteh A, Abdullah LC, Biak DRA, Madaeni SS, Abidin ZZ. "Review of technologies for oil and gas produced water treatment". Journal of Hazardous Materials, 170(2-3), 530-551, 2009.

[4] Razi FA, Alireza P, Zainal AZ, Chuah AL, Awang BDA, Siavash MS. "Application of membrane-coupled sequencing batch reactor for oilfield produced water recycle and beneficial re-use". Bio Resource Technology, 101(18), 6942-6949, 2010.

[5] Hashim R, Abdolhamid, Al-baghdadi MARS, El hinshiri AK. "Evaluation of bio-surfactants enhancement on bioremediation process efficiency for crude oil contaminated soil at oilfield". Strategic Study, 20, 25-30 2009.

[6] Veil JA, Markus G, Puder, Elcock D, Robert J, Redweik J. “A White Paper Describing Produced Water From Production Of Crude Oil". Natural Gas and Coal Bed Methane Produced Water P0401pdf, USA, Technical Report, 2004.

[7] Zhaohui X, Ashok M, Wilfred C. "Detection of benzene, toluene, ethyl benzene and xylenes (BTEX) using toluene dioxygenase-peroxidase coupling reactions". Biotechnology Progress, 19(6), 1812-1815, 2003.

[8] Agency USEP. "National center for environmental assessment-Washington office of research and development". Carcinogenic Effects of Benzene: An Update, Washington, DC, 571998.

[9] Reusser DE, Field JA. "Determination of benzyl succinicacid in gasoline-contaminated ground water by solid-phase extraction coupled with gas chromatography". Mass Spectrometry, 953, 215-225, 2002.

[10] Halliburton. "Water management [online]". http://www.halliburton.com (17.09.2011).

[11] James PR, Rainer EF. "Produced Water". Technological/Environmental Issue and Solutions. In Environ. Sci. Res. pp 6161993.

[12] Khatib Z, Verbeek. "Water to Value Produced Water Management for Sustainable Field Development of Mature and Green Fields". Journal of Petroleum Technology, 55(1), 26-28, 2003.

[13] Andresen PAK, Arntzen R, Sjøblom J. "Stability of model emulsions and determination of droplet size distributions in a gravity separator with different inlet characteristics". Colloids and Surfaces A, 170(1), 33-44, 2000 . 
[14] Klasson KT, Taylor PA, Walker JF, Jr, Jones SA, Cummins RL, Richardson SA. "Modification of a centrifugal separator for in-well oil-water separation". Separation Science and Technology, 40(1-3), 453-462, 2005.

[15] Wang Y, James PW. "Calculation of wave-plate demister efficiencies using numerical simulation of the flow field and droplet motion". Chemical Engineering Research and Desing, 76(48), 980-985, 1998.

[16] Zhao Y, Hua W, Wang YJ, Ma SC, Yan J. "Numerical simulation of separation efficiency of demisters with serrated baffles in wet flue gas desulfurization towers". Journal of Chinese Society of Power Engineering, 25, 293-297 2005.

[17] Zhong WQ, Xiong YQ, Yuan ZL, Zhang MY. "DEM simulation of gas-solid flow in a spout-fluid bed". Chemistry Engineering Sciences, 61(5), 1571-1584, 2006.

[18] Cooper S, Coronellat CJ. "CFD simulations of particle mixing in a binary fluidized bed". Powder Technology, 151(1-3), 27-36, 2005.

[19] Nowakowski AF, Cullivan JC, Williams RA, Dyakowski T. "Application of CFD to modeling of the flow in hydrocyclones. Is this a realizable option or still a research challenge?". Minerals Engineering, 17(5), 661-669, 2004.

[20] Ansys Fluent Guide (ANSYS FLUIENT). Theory And Guide in 2009.

[21] Computational Analysis for Multi-Phase Flow in Helical Water Oil Separator Using (Cfd) Submitted to The College of Graduate Studies. Texas A\&M UniversityKingsville In Partial Fulfillment of The Requirements For The Degree Of Master Science, May, 2006.

[22] Abdurahmann H, Nour, Mohd A, Hassan A, Yunus RM. "Characterization and demulsification of water-in-crude oil emulsions". Journal Applied Sciences, 7(10), 1437-1441, 2007.
[23] Chen L, Wul S, Lu H, Huang K, Zhao L. "Numerical simulation and structural optimization of the inclined oil/water separator". PLoS ONE, 10(4), 1-15, 2015.

[24] Brackbill JU, Kothe DB, Zemach C. "A continuum method for modeling surface tension". Journal of Compututational Physics, 100(2), 335-354 1992.

[25] Mastouri R. "A Time to Review The Produced Water Treatment Technologies, A Time To Look Forward For New Management Policies". Islamic Azad University, Arak Branch Civil Engineering Faculty, Daneshgah Street Arak, Iran 2010.

[26] Schlieper L, Chatterjee M, Henschke M, Pfennig A. “ Liquid-Liquid Phase Separation in Gravity Settler with Inclined Plates." Published online in Wiley Inter Science: www.interscience.wiley.com , April 2004.

[27] Ivanenko A, Yablokova YU, Petrov SI. "Simulation of the separation of emulsified oil products from water in an apparatus with sinusoidal profiled oleophilic plates". Theoretical Foundations of Chemical Engineering, 44(5), 729-741, 2010.

[28] Paulo AB, Sampaioa, Jose LH, Faccinia, B, Su J. “Modeling of stratified gas-liquid two-phase flow in horizontal circular pipes". International Journal of Heat and Mass Transfer, 51(11-12), 2752-2761 2008.

[29] Yayla S, Sabah S, Olcay AB. "The separation of Water and Oil in Water Treatment Plant in Petroleum Project using Coalescing Plate Seperator and CFD Simulatio". International Congress on Engineering and Information (ICEAI), Osaka, Japan, 10-12 May, 2016. 